\title{
PENERAPAN MODEL PEMBELAJARAN KOOPERATIF TEKNIK MAKE A MATCH UNTUK MENINGKATKAN PRESTASI BELAJAR SISWA PADA MATA PELAJARAN MEKANIKA TEKNIK KELAS X TEKNIK BANGUNAN SMK NEGERI 5 SURAKARTA TAHUN AJARAN $2014-2015$
}

Dewi Ardiyawati ${ }^{1}$, Anis Rahmawati ${ }^{2}$, Rima Sri Agustin ${ }^{3}$

\begin{abstract}
ABSTRAK
Tujuan penelitian adalah (1) Untuk mengetahui peningkatan peran aktif siswa dalam proses belajar mengajar dengan model pembelajaran kooperatif teknik Make a Match, (2) Untuk mengetahui peningkatan prestasi belajar siswa pada mata pelajaran Mekanika Teknik dengan model pembelajaran kooperatif teknik Make a Match. Penelitian ini merupakan Penelitian Tindakan Kelas (PTK). Penelitian dilaksanakan dalam dua siklus, dengan tiap siklus terdiri atas perencanaan, pelaksanaan, pengamatan dan refleksi. Teknik pengumpulan data yang digunakan adalah observasi, dokumentasi, tes dan tugas. Uji validitas data menggunakan teknik triangulasi data dan analisis data secara analisis interaktif. Hasil penelitian menunjukkan (1) Model pembelajaran kooperatif teknik Make a Match dapat membuat siswa berperan aktif dalam proses belajar mengajar, (2) Prestasi Belajar siswa: Ranah Kognitif pada pra siklus 29,17\%, Siklus I 66,67\% dan Siklus II 83,33\%; Ranah Afektif pada pra siklus berpredikat Baik (B) 8 siswa, Siklus I berpredikat Sangat Baik (SB) 2 siswa dan berpredikat Baik (B) 12 siswa, dan Siklus II berpredikat Sangat Baik (SB) 5 siswa dan 19 siswa berpredikat Baik (B); Ranah Psikomotorik pada pra siklus 25,00\%, Siklus I 62,50\% dan Siklus II $83,33 \%$. Simpulan penelitian ini adalah penerapan model pembelajaran kooperatif teknik Make a Match dapat meningkatkan peran aktif siswa dalam mengikuti pembelajaran. Penerapan model pembelajaran kooperatif teknik Make a Match meningkatkan prestasi belajar siswa kelas X TSB SMK Negeri 5 Surakarta pada mata pelajaran Mekanika Teknik.
\end{abstract}

Kata Kunci: Make a Match, Prestasi Belajar, Mekanika Teknik

1 Pendidikan Teknik Bangunan Universitas Sebelas Maret

2,3 Dosen Pendidikan Teknik Bangunan Universitas Sebelas Maret 


\title{
APPLICATION OF COOPERATIVE LEARNING MODEL MAKE A MATCH TECHNIQUE TO IMPROVE STUDENTS ACHIEVEMENT IN MECHANICAL ENGINEERING SUBJECT AT CLASS X BUILDING ENGINEERING AT VOCATIONAL HIGH SCHOOL 5 SURAKARTA YEAR OF 2014 - 2015 Dewi Ardiyawati ${ }^{1}$, Anis Rahmawati ${ }^{2}$, Rima Sri Agustin ${ }^{3}$
}

\begin{abstract}
The purpose of this study were (1) To determine the increase in the active role of students in the learning process with a model of cooperative learning Make a Match techniques, (2) To determine the increase in student achievement in the subjects of engineering mechanics with cooperatif learning Make a Match techniques. This study uses a class action (PTK). The research were conducted in two cycles, with each cycle consisting of planning, implementation, observation and reflection. Data collection techniques using observation, documentation, tests and assigment. The validity test of the data using data triangulation and data analysis according to interactive analysis. The results showed (1) The model of cooperative learning techniques Make a Match could make students actively involved in the learning process, (2) Students achievement: Cognitive Domains at $29,17 \%$ pre-cycle, the first cycle $66,67 \%$ and the second cycle 83,33\%; Affective domain of the pre-cycle predicated Good (B) 8 students, the first cycle predicated Very Good (SB) 12 students, and the second cycle predicated Very Good (SB) 5 students and 19 students predicated Good (B); Psychomotor domains at 25,00\% pre-cycle, the first cycle $62,50 \%$ and the second cycle $83,33 \%$. The conclusions of this study was the implementation of cooperative learning model of Make a Match technique could enhance students active role in participating in learning. The implementation of cooperative learning model of Make a Match technique improve students achievement class X-TSB vocational high school 5 Surakarta on the subjects of Mechanical Enginering.
\end{abstract}

Keywords: Make a Match, Learning Achievement, Mechanical Enginering

1 Vocational Technical Education, Sebelas Maret University

2,3 Leaturer Vocational Technical Education, Sebelas Maret University 


\section{PENDAHULUAN}

Pendidikan dikatakan maju dengan adanya hasil akhir dari pembelajaran. Prestasi belajar yang dicapai peserta didik merupakan tolok ukur untuk mengetahui seberapa jauh materi pelajaran yang dapat diserap oleh peserta didik. Selain itu kualitas pembelajaran dan kualitas guru juga sangat berpengaruh dalam proses belajar mengajar.

Kualitas pembelajaran dapat dilihat dari dua sisi yang sama pentingnya, yakni proses dan hasil belajar. Proses belajar berkaitan dengan pola perilaku siswa dalam mempelajari bahan pelajaran, sedangkan hasil belajar berkaitan dengan perubahan perilaku yang diperoleh sebagai pengaruh dari proses belajar. Hasil belajar merupakan salah satu faktor yang dapat menentukan proses belajar. Dengan kata lain, bagaimana seharusnya siswa belajar, akan sangat ditentukan oleh apa hasil yang ingin diperoleh oleh siswa. Manakala kriteria keberhasilan belajar siswa diukur dari seberapa banyak materi pelajaran dapat dikuasai siswa, akan berbeda proses belajar yang dilakukan dengan kriteria keberhasilan ditentukan oleh sejauh mana siswa dapat memanfaatkan potensi otaknya untuk memecahkan suatu persoalan.

Komponen guru merupakan salah satu komponen yang menentukan keberhasilan proses belajar siswa, sebab guru merupakan ujung tombak yang secara langsung berhubungan dengan siswa sebagai objek dan subjek belajar. Berkualitas dan tidaknya proses pembelajaran sangat tergantung pada kemampuan dan perilaku guru dalam pengelolaan pembelajaran.

Undang - Undang Nomor 14 Tahun 2006 tentang Guru dan Dosen, Bab 1 Pasal 1 menjelaskan bahwa guru adalah pendidik profesional dengan tugas utama mendidik, mengajar, membimbing, mengarahkan, melatih, menilai, dan mengevaluasi peserta didik pada pendidikan anak usia dini jalur pendidikan formal, pendidikan dasar, dan pendidikan menengah.

Berdasarkan undang

undang tersebut, ada dua hal yang perlu digaris bawahi. Pertama, Guru adalah jabatan profesional, yakni jabatan yang hanya dapat dilakukan oleh orang - orang yang memiliki latar belakang akademik keguruan. Dengan demikian, tidak setiap orang dapat memjadi guru profesioanl. Kedua, tugas guru yang profesioanal itu adalah mendidik, mengajar, membimbing, mengarahkan, melatih, menilai, dan mengevaluasi. Dengan demikian, melalui tugas yang begitu berat itu, keberhasilan pembentukan peserta didik atau pembentukan generasi manusia ada di pundak guru.

Dari uraian diatas, kita mengetahui bahwa pendidikan tidak hanya dilihat dari prestasi belajar yang diperoleh akan tetapi dilihat dari pendidiknya juga. Oleh karena itu pada saat proses belajar mengajar peran pendidik sangat penting dalam menyampaikan materi. Seperti halnya dengan mata pelajaran mekanika teknik. Mekanika teknik mempunyai peran strategis dalam proses pendidikan karena ilmu yang didapat bisa diterapkan dalam perhitungan dilapangan. 
Dalam pembelajaran di sekolah tingkat Sekolah Menengah Kejuruan (SMK) bidang teknologi dan rekayasa seringkali mekanika teknik masih dianggap sulit oleh peserta didik. Banyak siswa yang masih kurang berantusias untuk mengikuti mata pelajaran mekanika teknik. Hal ini disebabkan mereka beranggapan bahwa mata pelajaran mekanika teknik sama halnya mata pelajaran matematika yang tidak luput dari perhitungan angka. Akibatnya sering kali siswa kurang bersemangat pada saat mengikuti mata pelajaran mekanika teknik.

Dari data yang diperoleh dari proses observasi ke SMK N 5 Surakarta pada mata pelajaran mekanika teknik khususnya pada materi analisis rangka batang nilai rata - ratanya adalah 45,50 dari KKM 75. Siswa yang sudah lulus dari KKM yang ditentukan hanya 7 siswa dari 24 siswa dengan persentase $29,17 \%$.

Data diatas menyebutkan bahwa prestasi belajar mekanika teknik khususnya pada SMK N 5 Surakarta masih rendah. Salah satu faktor yang menyebabkan rendahnya prestasi belajar mekanika teknik mungkin cara mengajar guru yang masih menggunakan pembelajaran konvensional. Pembelajaran konvensional yang dilakukan pada saat proses diskusi masih menggunakan diskusi yang sederhana. Sederhana yang dimaksud adalah guru membagi siswa dalam beberapa kelompok kemudian guru memberikan soal yang ditulis dipapan tulis dan siswa menyelesaikan soal tersebut. Dalam pembelajaran tersebut siswa kurang berperan aktif dalam mengikuti pembelajaran. Hal ini memyebabkan prestasi belajar siswa menjadi tidak maksimal.

Model pembelajaran teknik Make a Match atau mencari pasangan dikembangkan oleh Lorna Curran (1994). Salah satu keunggulan teknik ini adalah siswa mencari pasangan sambil mempelajari suatu konsep atau topik tertentu dalam suasana yang menyenangkan. Teknik ini bisa diterapkan untuk semua mata pelajaran dan tingkatan kelas (Huda, 2015 : 135).

Model pembelajaran kooperatif teknik Make a Match terpusat pada siswa sehingga siswa dapat mengikuti pelajaran dengan aktif. Model pembelajaran kooperatif teknik Make a Match didasarkan pada ketrampilan siswa menemukan informasi dan kerjasama dengan siswa lain. Hal ini terlihat ketika salah satu siswa harus menjawab pertanyaan dan mencari pasangan soalnya. Siswa menjawab pertanyaan sesuai dengan kartu soal yang diterima. Dalam model pembelajaran kooperatif teknik Make a Match siswa dapat berkomunikasi dan bekerjasama antar siswa. Dalam pembelajaran dengan menggunakan teknik Make a Match siswa mencari pasangan mengenai konsep atau topik tertentu dalam suasana yang menyenangkan.

Penggunaan model pembelajaran kooperatif teknik Make a Match siswa dapat berperan aktif dan melatih berkomunikasi serta melatih bekerjasama antar siswa lain. Hal tersebut dapat meningkatkan prestasi belajar siswa. Dengan penggunaan metode dan teknik baru 
siswa lebih besemangat dalam mengikuti proses pembelajaran.

$$
\text { Menurut Hamzah (2011) }
$$

dalam skripsi Septiarini menyatakan:Siswa yang berperan aktif yaitu siswa yang terlibat dalam kegiatan pembelajaran untuk berpikir, berinteraksi, berbuat untuk mencoba, menemukan konsep baru atau menghasilkan suatu karya. Dalam beberapa penelitiannya, siswa yang berperan aktif adalah siswa yang belajar dari pengalamannya, selain siswa harus belajar memecahkan masalah yang diperoleh. Indikator peran aktif dalam penelitian ini yaitu: (1) Keaktifan dalam berdiskusi, (2) Keaktifan bertanya, (3) Membantu teman atau kelompok lain dalam menyelesaikan masalah.

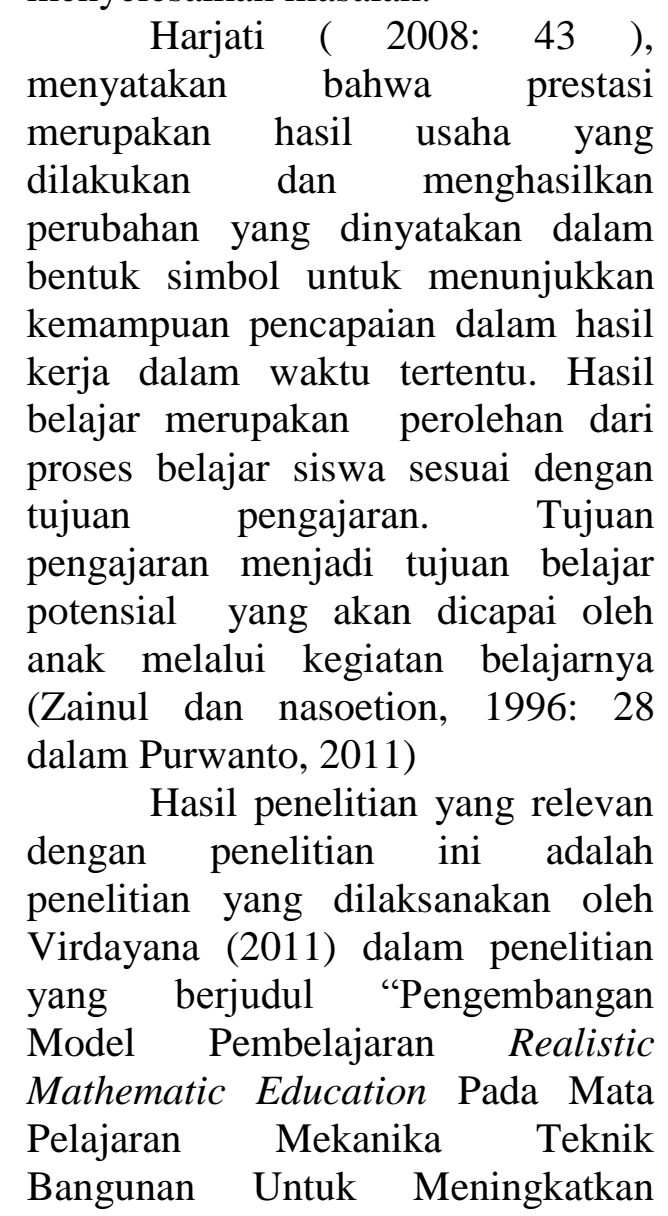

Efektifitas Hasil Dan Proses Belajar" menyimpulkan hasil penelitian dan pengembangan model pembelajaran kooperatif dengan metode Realistic Mathematic Education (RME) pada Mekanika Teknik Bangunan (MTB) dengan kompetensi dasar menghitung gaya normal garis momen, gaya lintang, garis momen, dan momen maksimal untuk meningkatkan efektifitas proses dan hasil belajar XI SMK Negeri 5 Surakarta. (1). Hasil belajar uji kompetensi (kognitif) meningkat, pada siklus I ketuntasan setiap kelas sebesar, kelas XI TGB 70\%, kelas XI TKB $72,41 \%$ dan kelas XI TKK $70,83 \%$ dan siklus II sebesar kelas XI TGB 88,67\%\%, kelas XI TKB $89,66 \%$ dan kelas XI TKK 83,33\%. (2). Hasil pembelajaran secara proses (afektif) meningkat,dapat dilihat dari hasilpada siklus I ketuntasan setiap kelasnya sebesar, kelas TGB $69,38 \%$, TKB 70,45\% dan TKK $70,21 \%$, dan siklus II sebesar kelas TGB $71.18 \%$, TKB 73,29\% dan TKK 72,37\%. Hasil observasi menunjukkan peningkatan di setiap aspek, dari uji coba tahap I ke uji coba tahap II prosentase meningkat meski tidak terlalu tajam peningkatannya, hal ini dapat menunjukkan bahwa dengan mengunakan pengembangan model pembelajaran RME dapat meningkatkan proses pembelajaran peserta didik di kelas maupun diluar kelas.

Penelitian yang dilaksanakan Henny Ambarwati (2012) dalam penelitian yang berjudul "Penerapan Model Pembelajaran Make a Match dalam Upaya Meningkatkan Hasil Belajar Sejarah Siswa SMA Kristen Satya Wacana Salatiga Semester 
Gasal Tahun Ajaran 2011/2012" menyimpulkan bahwa rata-rata hasil belajar pada kondisi awal 77,4 dengan prosentase ketuntasan $89,6 \%$. Setelah dilakukan tindakan kelas dengan menerapkan model pembelajaran Make a Match diperoleh rata-rata hasil belajar pada siklus I sebesar 77,5 dengan ketuntasan klasikal 96,3\% dan ratarata hasil belajar pada siklus II sebesar 95,9 dengan ketuntasan klasikal 100\%. Berdasarkan hasil penelitian dapat disimpulkan bahwa penerapan model Make a Match dapat meningkatkan hasil belajar Sejarah dan menuntaskan siswa kelas X-5 SMA Kristen Satya Wacana Salatiga Semester Gasal Tahun Ajaran 2011/2012.

Berdasarkan latar belakang dan kajian teori yang telah dipaparkan sebelumnya, maka tujuan dari penelitian ini adalah sebagai berikut: (1) Untuk mengetahui peningkatan peran aktif siswa dalam proses belajar mengajar dengan model pembelajaran kooperatif teknik Make a Match, (2) Untuk mengetahui peningkatan prestasi belajar siswa pada mata pelajaran Mekanika Teknik dengan model pembelajaran kooperatif teknik Make a Match.

\section{METODE PENELITIAN}

Penelitian dilaksanakan di SMK N 5 Surakarta yang beralamat di Jl. LU. Adisucipto No 42 Telp. (0271) 713916 Fax 727068 Surakarta 57143. Jenis penelitian ini adalah penelitian tindakan kelas (PTK) atau Classroom Action Research. Penelitian tindakan kelas (PTK) adalah suatu bentuk penelitian reflektif dan kolektif yang dilakukan oleh peneliti dalam situasi sosial untuk meningkatkan penalaran praktik sosial mereka (Kemmis, 1988). Menurut Elliot (1982), penelitian tindakan adalah kajian tentang situasi sosial dengan maksud untuk meningkatkan kualitas tindakan melalui proses diagnosis, perencanaan, pelaksanaan, pemantauan, dan mempelajari pengaruh yang ditimbulkan. (Sanjaya,2013:24-25). Subjek penelitian ini adalah kelas X TSB SMK Negeri 5 Surakarta Tahun Ajaran 2014/2015. Kelas X TSB terdapat 24 siswa yang terdiri dari 2 siswa perempuan dan 22 siswa lakilaki. Teknik pengumpulan data dalam penelitian ini menggunakan (1) observasi, (2) dokumentasi, (3) tes dan (4) tugas. Untuk menghasilkan informasi yang akurat dan memastikan kebenaran data, maka dalam penelitian ini menggunakan teknik triangulasi data. Pada penelitian ini teknik analisis data yang dilakukan secara analisis interaktif, yang terdiri dari reduksi data, penyajian data, dan penarikan kesimpulan dalam bentuk interaktif dengan pengumpulan data sebagai suatu proses siklus. Indikator Kinerja Penilaian untuk peran aktif nilai yang ditargetkan Tinggi, Baik, Aktif dimana aspek yang diukur meliputi (1) keaktifan diskusi, (2) keaktifan bertanya, (3) membantu kelompok lain. Indikator Kinerja Penilaian Prestasi Belajar untuk ranah kognitif dan psikomotorik nilai yang ditargetkan 75 dan indikator prestasi $75 \%$, untuk ranah afektif predikat yang ditargetkan Baik (B). Prosedur penelitian (1) pra tindakan dan (2) Tindakan. Dalam pelaksanaan tindakan terdapat dua siklus, setiap siklus terdiri dari (a) perencanaan, 
(b) pelaksanaan, (c) pengamatan, dan

(d) refleksi.

\section{HASIL PENELITIAN DAN PEMBAHASAN}

Hasil tindakan pra siklus peran aktif masih ada siswa yang kurang memperhatikan guru pada saat penyampaian materi maupun pelaksanaan diskusi kelompok. Berikut diagram peran aktif siswa pra siklus

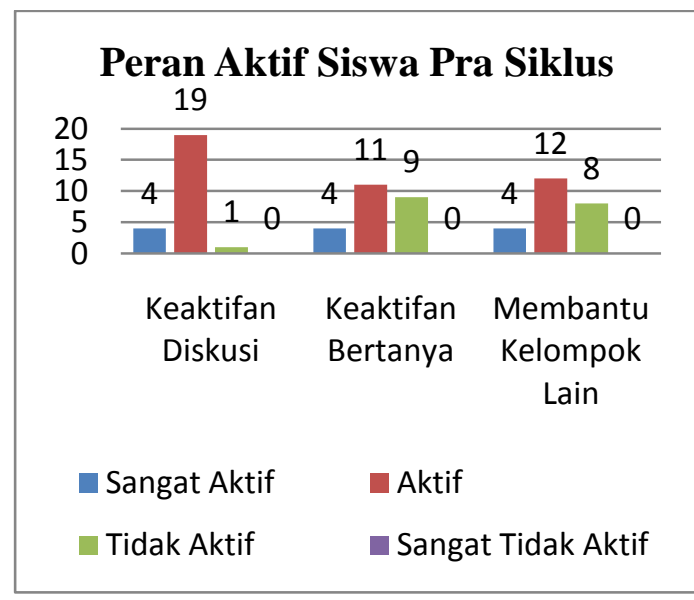

Gambar 1. Diagram Predikat Peran

Aktif Siswa Pra Siklus

Keaktifan diskusi, keaktifan bertanya dan membantu kelompok lain masih kurang meskipun sudah ada beberapa siswa yang mulai aktif. Untuk keaktifan diskusi masih ada 2 siswa yang tidak aktif dalam mengikuti pelaksanaan diskusi. Keaktifan bertanya pada saat pembelajaran berlangsung masih ada 9 siswa yang malu untuk bertanya apabila mengalami kesulitan. Pada saat proses pembelajaran berlangsung siswa saling membantu teman apabila mengalami kesulitan, meskipun masih ada 8 siswa yang kurang aktif dalam berinteraksi dengan teman lainnya.
Prestasi belajar siswa pra siklus yang mencapai nilai $\geq 75$ masih sangat jauh dari terget ketuntasan yang ditetapkan dalam penelitian yaitu $75 \%$.

Berikut diagram prestasi belajar siswa: ranah kognitif, ranah afektif dan ranah psikomotorik.
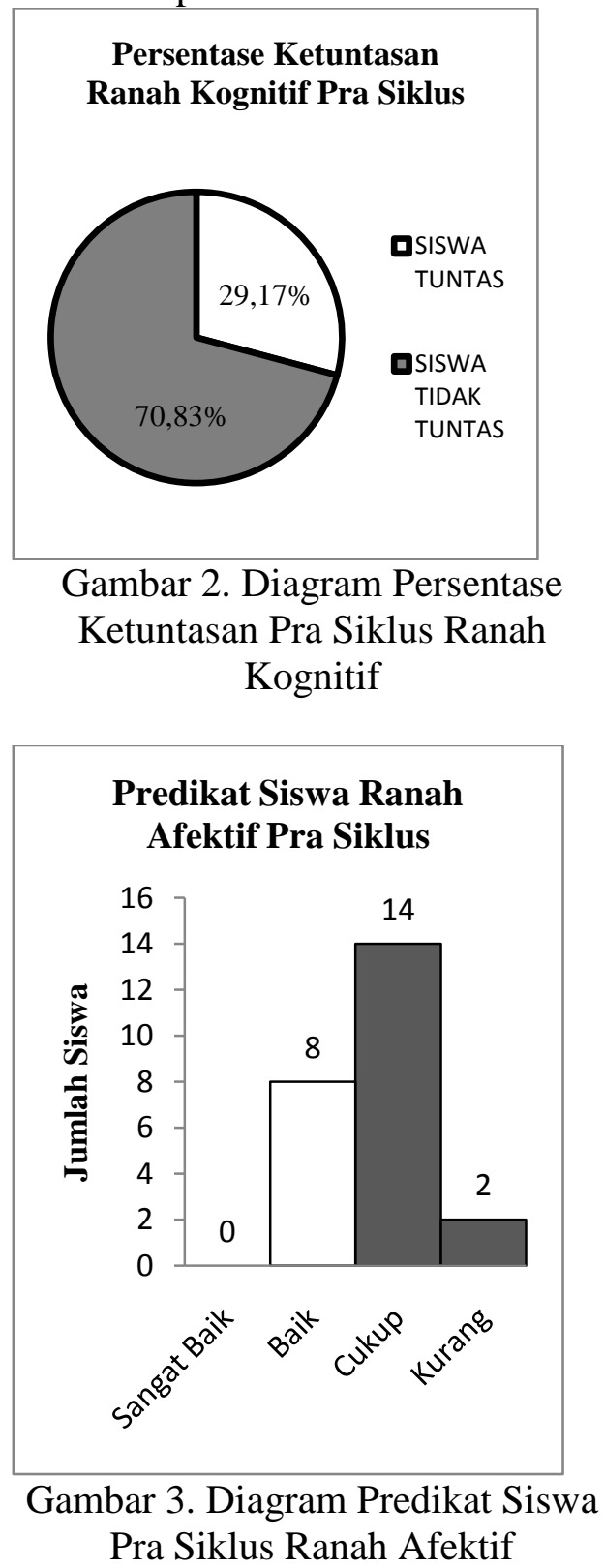


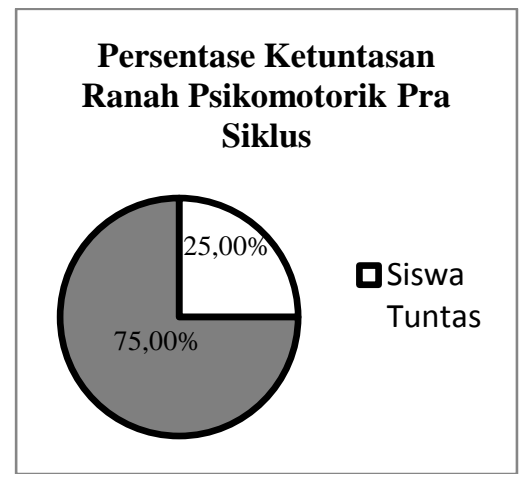

Gambar 4. Diagram Persentase Ketuntasan Pra Siklus Ranah Psikomotorik

Pada hasil ranah kognitif didapat rata-rata sebesar 40,45 dengan persentase ketuntasan $29,17 \%$ dengan 7 siswa dari 24 siswa. Untuk hasil ranah afektif siswa yang mendapatkan predikat Sangat Baik dan Baik (B) sebanyak 8 siswa dari 24 siswa. Hasil ranah kognitif didapat rata-rata sebesar 75,83 dengan persentase ketuntasan $25,00 \%$ dengan 15 siswa dari 24 siswa.

Dari peran aktif siswa dan prestasi belajar siswa yang diperoleh masih sangat jauh dengan indikator yang telah ditetapkan. Hal ini terjadi karena siswa dalam mengikuti pembelajaran masih kurang aktif dalam bertanya maupun dalam pelaksanaan diskusi, sehingga hasil yang diperoleh juga kurang maksimal. Untuk menumbuhkan peran aktif siswa dalam pelaksanaan pembelajaran maka dilakukan adanya metode pembelajaran baru dengan menggunakan model pembelajaran kooperatif teknik Make a Match untuk meningkatkan peran aktif siswa dan prestasi belajar siswa.

Pelaksanaan Siklus I peran aktif siswa mengalami peningkatan, siswa yang biasanya tidak memperhatikan saat penyampaian materi sudah mulai memperhatikan apa yang disampaikan guru. Pada saat pelaksanaan diskusi kelompok masing-masing kelompok sudah mulai bertanggung jawab dalam melaksanakan tugas masing-masing. Berikut diagram peran aktif siswa siklus I

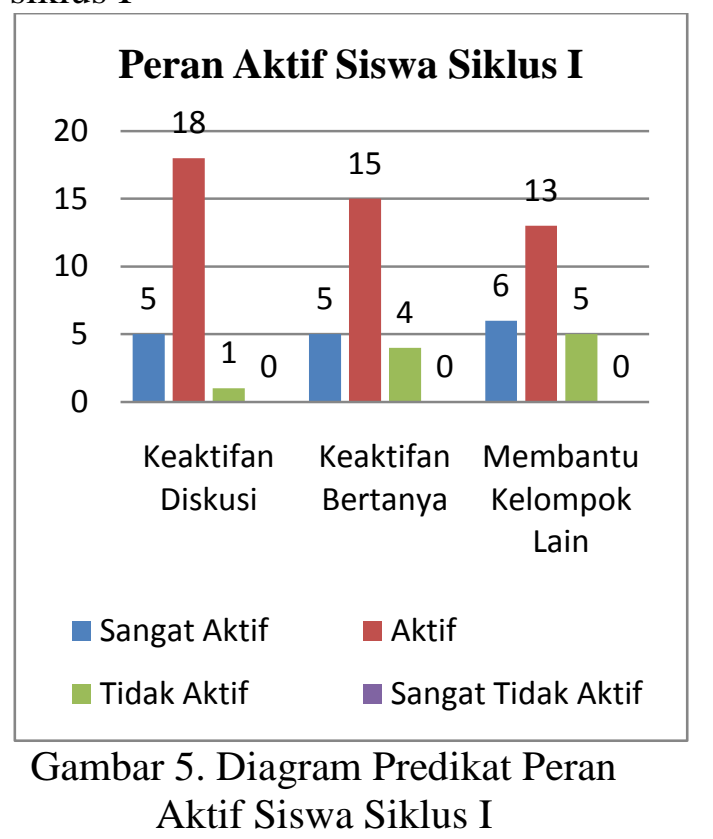

Siklus I keaktifan diskusi, keaktifan bertanya maupun membantu kelompok lain sudah mengalami peningkatan dari hasil pra siklus. Siswa yang kurang aktif dalam mengikuti pembelajaran sudah mulai berkurang. Contohnya pada keaktifan diskusi hanya terdapat 1 siswa yang kurang aktif dalam mengikuti diskusi, untuk keaktifan bertanya masih ada 4 siswa yang malu bertanya apabila menemukan permasalahan dan untuk membantu kelompok lain masih ada 5 siswa yang belum mampu membantu menyelesaikan masalah.

Berikut diagram prestasi belajar siklus I : ranah kognitif, ranah afektif dan ranah psikomotorik 


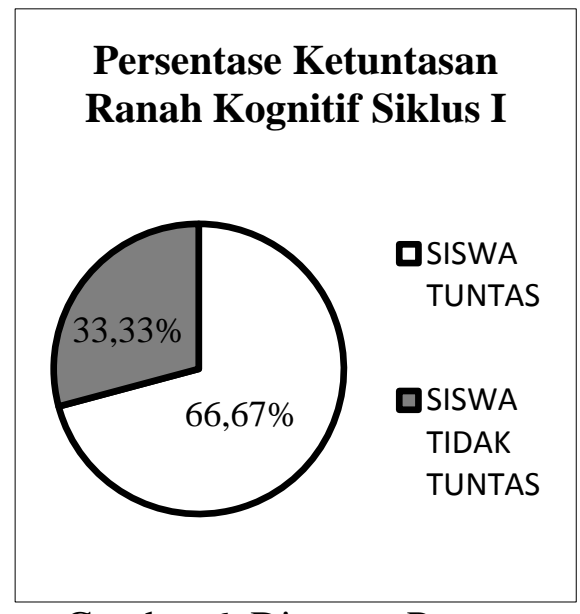

Gambar 6. Diagram Persentase Ketuntasan Siklus I Ranah Kognitif

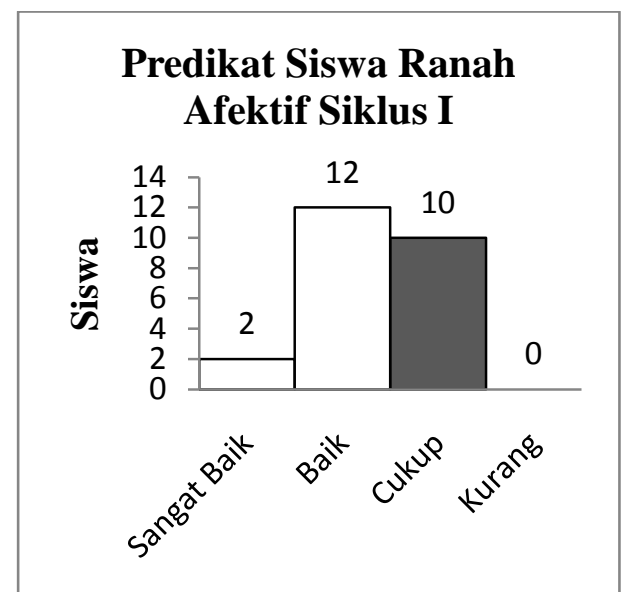

Gambar 7. Diagram Predikat Siswa Siklus I Ranah Afektif

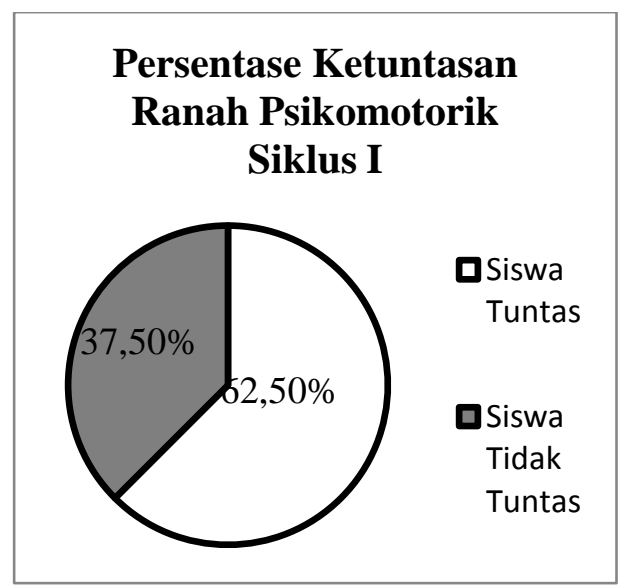

Gambar 8. Diagram Persentase Ketuntasan Siklus I Ranah Psikomotorik
Pada hasil ranah kognitif didapat rata-rata sebesar 60,50 dengan persentase ketuntasan $66,67 \%$ dengan 16 siswa dari 24 siswa. Hasil ranah afektif siswa yang mendapatkan predikat Sangat Baik (SB) dan Baik (B) sebanyak 14 siswa dari 24 siswa. Pada hasil ranah psikomotorik didapat rata-rata sebesar 76,46 dengan persentase ketuntasan $62,50 \%$ dengan 15 siswa dari 24 siswa.

Peran aktif siswa dan prestasi belajar siswa siklus I mengalami peningkatan. Siswa yang kurang aktif dalam mengikuti diskusi kelompok sudah mulai aktif mengikutinya. Selain itu prestasi belajar juga mengalami kenaikan baik ranah kognitif, afektif dan psikomotorik. Rata-rata nilai yang dicapai juga mengalami kenaikan dari prasiklus sampai siklus I. Penerapan model pembelajaran kooperatif teknik Make a Match dapat membuat siswa aktif dan meningkatkan prestasi belajar yang dicapai.

Pada saat pelaksanaan siklus II peran aktif siswa mulai mengalami peningkatan. Pada saat proses diskusi siswa sudah mulai bertanggung jawab dalam mengikuti diskusi. Berikut diagram peran aktif siswa siklus II 


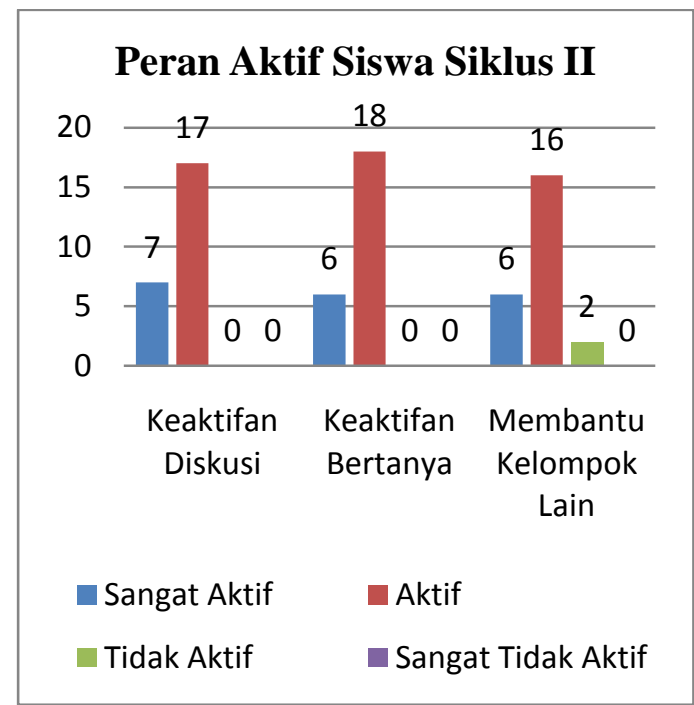

Gambar 9. Diagram Predikat Peran Aktif Siswa Siklus II

Pada pelaksanaan siklus II keaktifan diskusi mengalami peningkatan karena semua siswa sudah berperan aktif dalam mengikuti diskusi. Untuk keaktifan bertanya pada siklus II juga mengalami peningkatan, siswa sudah mulai berani dan aktif bertanya apabila mengalami kesulitan. Dalam pelaksanaan diskusi siswa sudah aktif dalam membantu teman yang mengalami kesulitan meskipun masih ada 2 siswa yang kurang aktif.

Berikut diagram prestasi belajar siklus I : ranah kognitif, ranah afektif dan ranah psikomotorik.

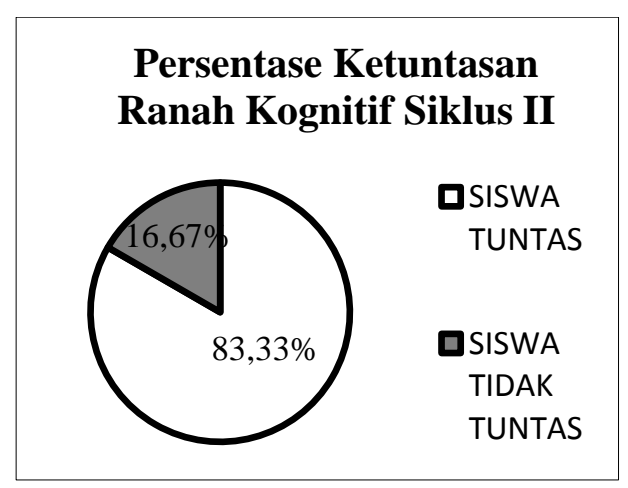

Gambar 10. Diagram Persentase Ketuntasan Siklus II Ranah Kognitif

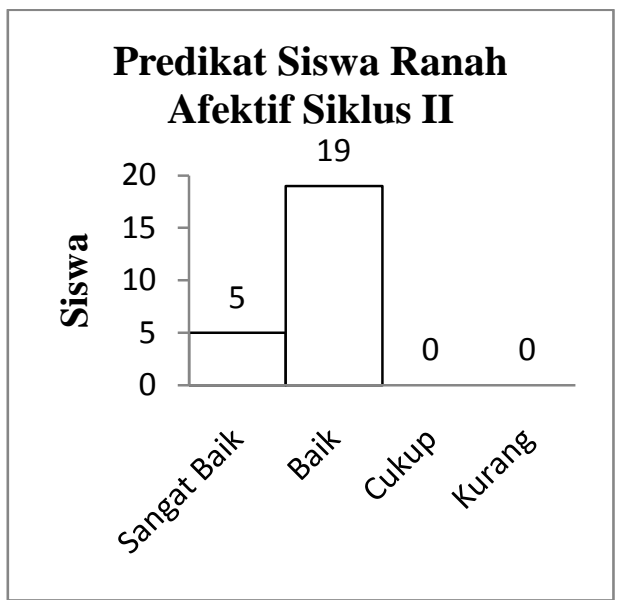

Gambar 11. Diagram Predikat Siswa Siklus II Ranah Afektif

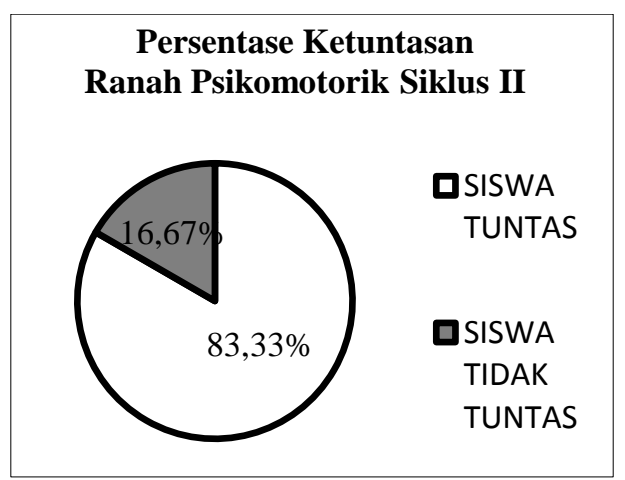

Gambar 12. Diagram Persentase Ketuntasan Siklus I Ranah Psikomotorik

Pada hasil ranah kognitif didapat rata-rata sebesar 68,71 dengan persentase ketuntasan $83,33 \%$ dengan 20 siswa dari 24 siswa. Hasil ranah afektif siswa yang mendapatkan predikat Sangat Baik (SB) 5 siswa dan Baik (B) sebanyak 19 siswa. Pada hasil ranah psikomotorik didapat rata-rata sebesar 82,71 dengan persentase ketuntasan 83,33\% dengan 20 siswa dari 24 siswa.

Peran aktif siswa dan prestasi belajar siswa siklus II mengalami peningkatan sangat baik. Siswa sangat antusias dalam mengikuti 
proses pembelajaran. Hal ini dapat dilihat dari keaktifan siswa dalam bertanya ketika penyampaian materi maupun proses diskusi kelompok. Siswa tidak lagi malu bertanya kepada guru maupun temannya apabila mengalami kesulitan. Kerjasama antar siswa sangat menonjol, siswa yang mengalami kesulitan bisa saling membantu dalam menjelaskan materi kepada temannya. Peran aktif yang mulai meningkat membuat prestasi belajar siswa juga mengalami peningkatan. Prestasi belajar siswa dari ranah kognitif, afektif dan psikomotorik semua mengalami kenaikan baik dari persentase ketuntasan maupun ratarata kelas.

Hasil penelitian dengan menerapkan metode pembelajaran kooperatif teknik Make a Match pada kelas X TSB SMK Negeri 5 Surakarta terbukti dapat meningkatkan peran aktif siswa dan prestasi belajar siswa. Semua aspek prestasi belajar seperti ranah kognitif, ranah afektif dan ranah psikomotorik mengalami peningkatan nilai ketuntasannya. Hal ini sejalan dengan hasil penelitian yang dilakukan oleh beberapa peneliti sebelumnya. Mereka menyimpulkan bahwa dengan menggunakan metode pembelajaran kooperatif teknik Make a Match dapat meningkatkan prestasi belajar siswa dan mempunyai pengaruh dalam keaktifan siswa.

\section{SIMPULAN}

Berdasarkan hasil penelitian dapat disimpulkan bahwa dengan menerapkan model pembelajaran kooperatif teknik Make a Match pada mata pelajaran Mekanika Teknik dengan materi menghitung gaya batang dengan metode analitis (titik buhul) dan cremona siswa kelas $\mathrm{X}$ TSB SMK Negeri 5 Surakarta: (1) Model pembelajaran kooperatif teknik Make a Match pada mata pelajaran Mekanika Teknik dapat meningkatkan peran aktif siswa dalam proses pembelajaran, (2) Model pembelajaran kooperatif teknik Make a Match dapat meningkatkan prestasi belajar siswa kelas $X$ TSB SMK Negeri 5 Surakarta pada mata pelajaran Mekanika Teknik. Secara teoritis penerapan model pembelajaran Make a Match dapat meningkatkan keaktifan siswa dalam proses pembelajaran. Make a Match dapat meningkatkan prestasi belajar siswa. Prestasi belajar siswa baik ranah kognitif, afektif, dan psikomotorik juga mengalami peningkatan. Penerapan model pembelajaran kooperatif teknik Make a Match dapat dijadikan perhatian guru untuk lebih selektif terhadap siswa yang hanya bergantung dalam kelompok.

\section{SARAN}

Bagi guru, model pembelajaran kooperatif teknik Make a Match dapat dijadikan sebagai alternatif pembelajaran pada mata pelajaran Mekanika Teknik maupun mata pelajaran lainnya. Pembelajaran dengan model pembelajaran kooperatif teknik Make a Match dapat meningkatkan peran aktif siswa dan prestasi belajar siswa.

Bagi siswa, siswa yang kurang aktif diminta untuk lebih aktif dalam mengikuti proses pembelajaran berlangsung baik ketika penyampaian materi maupun diskusi. Siswa yang memiliki rasa 
tanggung jawab rendah sebaiknya lebih bertanggung jawab dalam menjalankan tugas yang diterimanya. Jangan hanya mengandalkan salah satu teman dalam kelompoknya.

Bagi sekolah, adanya penelitian ini diharapkan dapat menjadi masukan bagi sekolah sehingga nantinya dapat melakukan perbaikan untuk meningkatkan kualitas proses pembelajaran di sekolah, khususnya di lingkungan SMK Negeri 5 Surakarta.

Bagi peneliti, penelitian hanya dilakukan pada materi menghitung gaya batang dengan metode analitis (titik buhul) dan cremona sehingga peneliti menganggap perlu dilakukan pengembangan model pembelajaran kooperatif teknik Make a Match pada materi yang lain.

\section{DAFTAR PUSTAKA}

Harjati. (2008). Model dan Teknik Penilaian Pada Tingkat Satuan Pendidikan. Jakarta: Gaung Persada Press

Henny Ambarwati (2012) Penerapan Model Pembelajaran Make a Match dalam Upaya Meningkatkan Hasil Belajar Sejarah Siswa SMA Kristen Satya Wacana Salatiga Semester Gasal Tahun Ajaran 2011/2012.

Huda, M. (2015). Cooperative Learning Metode, Teknik, Struktur Dan Model Penerapan. Yogyakarta: Pustaka Pelajar.

Jhptump-ump-gdl-septiarini-976-2babii.pdf. Diperoleh 2 September 2015, dari http://digilib.ump.ac.id/files/ disk1/20/jhptump-ump-gdlseptiarini-967-2-babii.pdf

Purwanto. 2011. Evaluasi hasil belajar. Pustaka belajar

Sanjaya,W. (2009). Penelitian Tindakan Kelas. Jakarta: Kencana Prenadamedia Group.

Virdayana (2011) Pengembangan Model Pembelajaran Realistic Mathematic Education Pada Mata Pelajaran Mekanika Teknik Bangunan Untuk Meningkatkan Efektifitas Hasil Dan Proses Belajar. 